\title{
PROPERTY VALUATION AND TAXATION FOR FISCAL SUSTAINABILITY - LESSONS FOR POLAND $^{1}$
}

\author{
Richard Grover, MRICS \\ School of the Built Environment \\ Oxford Brookes University \\ e-mail: rgrover@brookes.ac.uk \\ Marek Walacik, PhD \\ The Faculty of Geodesy, Geospatial and Civil Engineering \\ University of Warmia and Mazury in Olsztyn \\ e-mail: marek.walacik@uwm.edu.pl
}

\begin{abstract}
Research undertaken by the World Bank in Europe and the Central Asia Region indicates that there are four principal preconditions for introducing value-based recurrent property tax reforms: comprehensive property registration, a reliable source of data about the prices achieved in transactions, a valuation infrastructure that complies with internationally-recognized standards, and an efficient tax collection system. In spite of the arguments in favor of value-based recurrent property taxes, many countries raise revenue from recurrent property taxes using an area basis, and most countries raise relatively little revenue from recurrent property taxes. The paper has been written according to both the dogmatic-legal method and comparative method. It presents current solutions adopted in post-Soviet European countries in order to draw out recommendations and suggestions for Poland. The original reasoning for the paper is that, amongst many scientific papers concerning thorough debate of property tax systems, few have focused on post-Soviet countries and the issues that arise in transition countries. Most concern Western European or North American countries with different economies, politics, institutions, and histories to the Eastern ones. Authors of the paper believe that the article can fill the gap in discussions on the shape of the property tax system reform in Poland and the reforms carried out in Eastern Europe countries.
\end{abstract}

Key words: value-based recurrent property taxes, immovable property, property registration, property valuation.

JEL Classification: K11, K34, R28, R30, R58.

Citation: Grover R., Walacik M., 2019, Property Valuation and Taxation for Fiscal Sustainability - Lessons for Poland, Real Estate Management and Valuation, vol. 27, no. 1, pp. 35-48.

DOI: $10.2478 /$ remav-2019-0004

\footnotetext{
${ }^{1}$ The research on which this paper is based was financed by the World Bank ECA Region's Programmatic Trust Fund for Public Finance Management and the World Bank-FAO Cooperative Programme. We have benefitted from the work of our colleagues on the project: Anila Gjika and Elton Stafa (Albania), William McCluskey (Kazakhstan), Richard Almy, Albina Aleksienè and Arvydas Bagdonavičius (Lithuania); Olga Buzu (Moldova); Marco Kuijper and Ruud Kathmann (Netherlands); Marija Rasković and Olivera Jordanovic (Serbia); Neva Žibrik (Slovenia); and Ümit Yildiz and Tuğba Güneş (Turkey), and the supervisory team of Mika-Petteri Törhönen (World Bank), Paul Munro-Faure (FAO), and Aachal Anand (World Bank). They are not responsible for any errors in the article and the views expressed here are those of the authors and not necessarily theirs or those of the World Bank or the Food and Agriculture Organization of the United Nations.
} 


\section{Introduction - the role of value-based recurrent property taxes in a tax system}

Value-based recurrent property taxes can make an important contribution to the efficient functioning and fairness of a tax system. Their use reduces the reliance of a tax system on consumption taxes and those that fall upon incomes, employment, and profits (BARAŃSKA 2013; TROJANEK, KISIAEA 2018). These can have distorting effects on the balance between savings and consumption and between work and leisure, and on incentives for enterprise and to create employment. Savings, work and enterprise can be discouraged by taxes on incomes and profits, leading to sub-optimal choices. The employment of workers can be discouraged by the use of payroll taxes to generate social security contributions. By contrast, recurrent taxes on property are relatively neutral as they fall on accumulated wealth rather than influencing future behavior (NORREGAARD 2013). They can encourage the productive use of land in order to generate an income with which to pay the tax burden (MALME, YOUNGMAN 2001), thereby discouraging land hoarding and the keeping of land idle. Unlike property transfer taxes, recurrent property taxes do not incentivize the concealment of the true purchase price in order to reduce the tax burden (BUZU 2016; GÜNEŞ, YILDIZ 2016) or encourage informal transactions to evade taxation altogether.

The yields from taxes on profit and those that fall on high net wealth individuals are proving susceptible to globalization, which tends to reduce the revenue that can be derived from them. Reductions in tariff barriers have produced complex supply chains in which enterprises can source their inputs from many different countries and intermediate production can cross international frontiers several times before a final output is sold to the end user. This has many beneficial consequences including allowing international trade and wealth to increase, but the system can be gamed by multinational companies. They can use subsidiaries in different countries to supply each other in ways that enable transfer pricing to shift profits away from high tax jurisdictions. Subsidiaries in such countries buy inputs from ones located in low tax ones at inflated prices, thereby shifting the profits to low tax countries. Similarly, reductions in exchange control regulations enable subsidiaries of multinational companies to borrow from each other in such a way that tax deductible interest payments are made by subsidiaries in high tax jurisdictions, who are the borrowers, to ones in low tax countries, who are the lenders. Recurrent property taxes are amongst those least affected by globalization (JOHANSSON et al., 2008). There is no question of which jurisdiction immobile property assets are located in, irrespective of where the persons or legal entities that own them are domiciled for tax purposes or where they claim their economic activity is located. Taxes on these assets have to be paid irrespective of what tax minimization methods are used to demonstrate that profits are made or income earned elsewhere, or how impoverished the person or subsidiary appears to be.

Value-based recurrent property taxes can improve the equity of the tax system. They are a wealth tax, and thus the burden tends to fall on the part of the population which possesses assets. They can help produce a more progressive tax system by falling on those with wealth. By contrast, consumption taxes tend to fall particularly heavily on low income groups, which tend to have a higher marginal propensity to consume. They can also enhance inter-generational equity between households by taxing older households, who have been able to accumulate property assets, more heavily, whilst reducing the tax burden on younger households with fewer assets beyond their ability to generate income through work.

The ownership or occupancy of property assets indicates the ability to pay. Regular revaluations of recurrent property taxes mean that local communities can share in increases in land values that result from economic, demographic, and urban growth, which would otherwise just benefit landowners, but to which they have not contributed.

Recurrent property taxes are particularly valuable as local taxes. Unlike local sales taxes, the revenue from recurrent property taxes cannot leak across jurisdictional borders as the taxed assets are immobile. Consumers can avoid local sales taxes by doing their shopping in lower tax areas. The owners and occupiers of property have a stake in the local community and benefit from local public services, and their possession of property assets shows they have the ability to contribute financially to their supply. Well-designed recurrent property taxes can replace local taxes on businesses which can discourage enterprise, such as ones on business signage and licenses and permits, with taxes that are more neutral in their impact (RAŠKOVIĆ et al. 2016; GJIKA 2016). In some countries, central government budgets are under fiscal strain and the exploitation of the revenue-earning potential of local taxes, particularly recurrent property taxes, can reduce the need for intergovernmental fiscal 
transfers and relieve pressures on the central government. An argument can be made that increasing the proportion of the cost of local services met from local taxes improves governance. It helps to link taxation and local service provision by making citizens aware of the relationship between the two and the trade-offs that have to be made.

\section{Recurrent property tax capacity in the European Union}

Faced with these apparently compelling arguments, one would expect value-based recurrent property taxes to be heavily used. Recurrent property taxes are widely used. ALMY (2014) identified 166 countries which impose them. However, they are often used lightly, so that the revenue raised is limited. Figure 1 shows that there are significant variations in the burden from recurrent property taxes within the European Union (EU) when measured as a percentage of the Gross Domestic Product (GDP). The arithmetic average for the EU is 0.8 per cent. However, although the UK raises 3.4 per cent of its GDP in recurrent property taxes, France 2.4 per cent, and Denmark 2.1 per cent, 17 member states raise less than the EU average. Poland raises 1.2 per cent of its GDP in recurrent property taxes, which puts it in $8^{\text {th }}$ place in the EU. Fig. 1., Fig. 2.

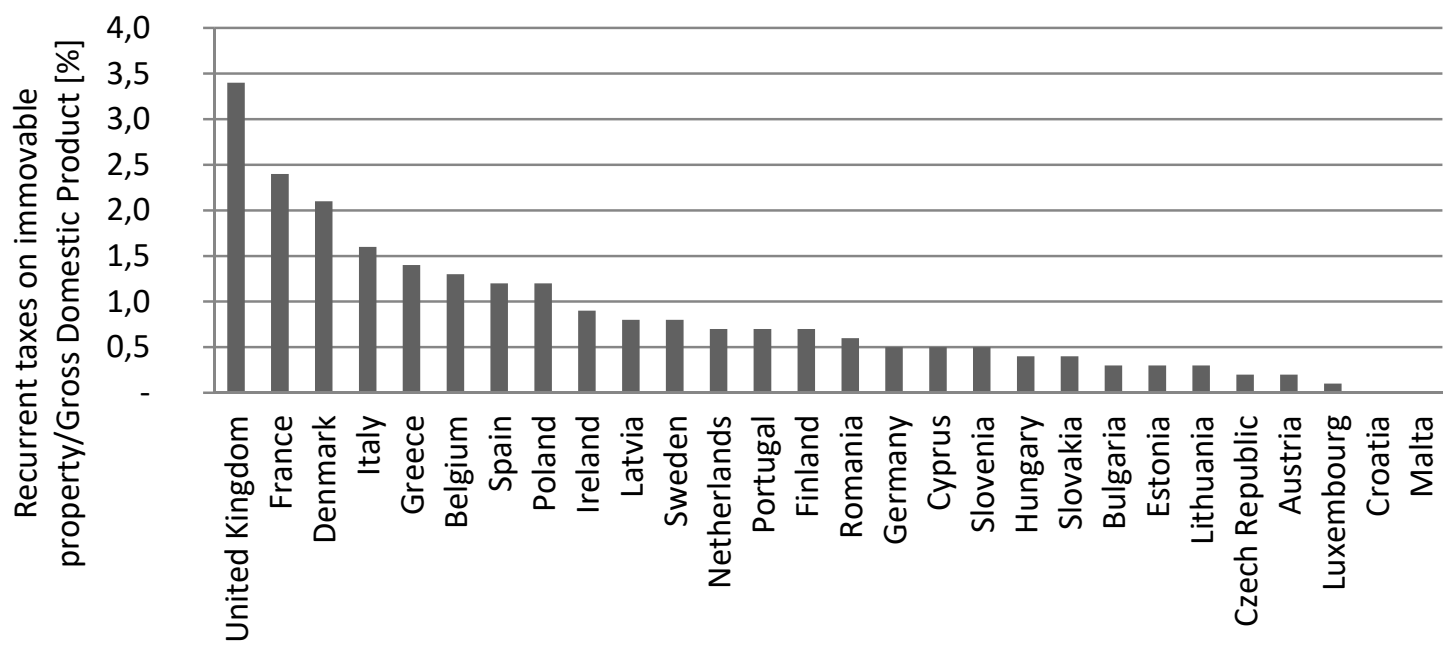

Countries of the European Union

Fig. 1 Recurrent taxes on immovable property as a percentage of Gross Domestic Product in countries of the European Union, 2012. Source: Eurostat (2014).

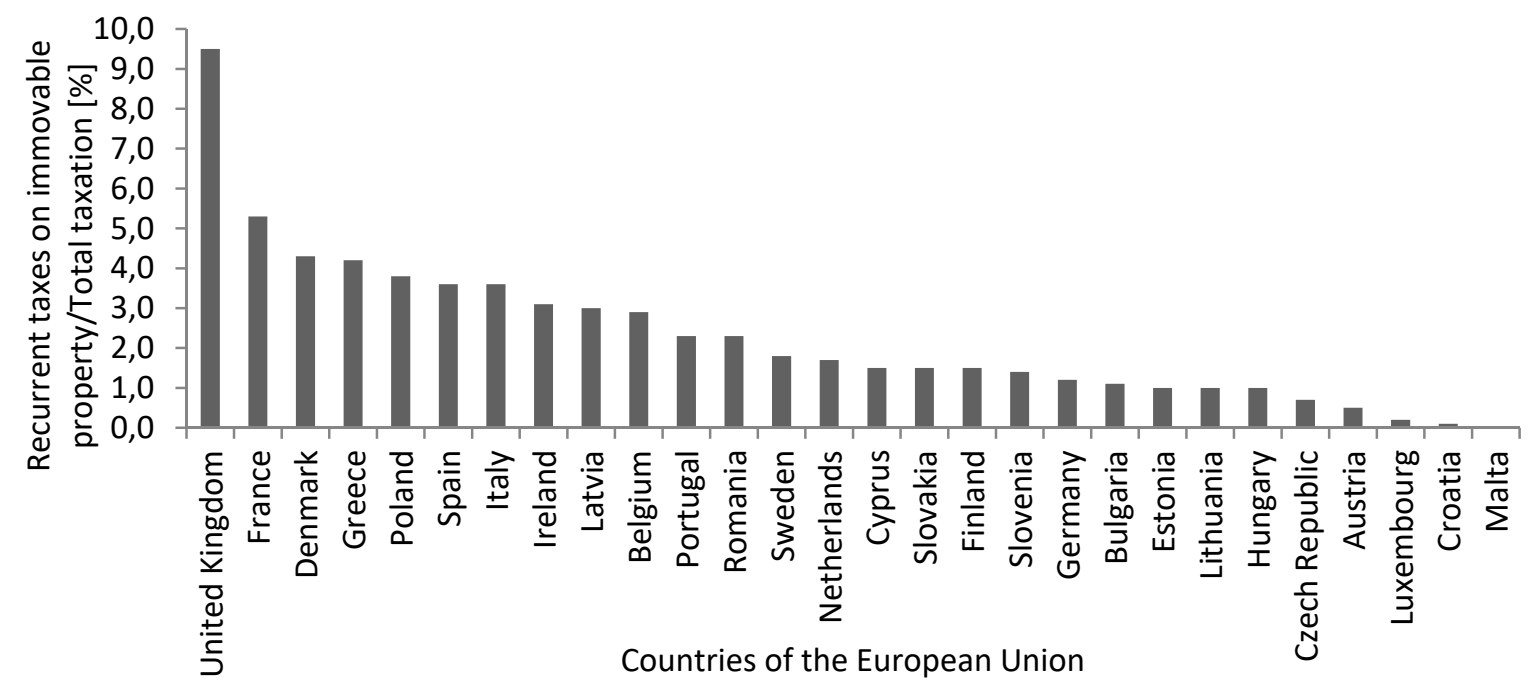

Fig. 2 Recurrent taxes on immovable property as a percentage of total taxation in countries of the European Union, 2012. Source: Eurostat (2014). 
Figure 2 shows recurrent property taxes as a percentage of total taxation within the EU. Again, there are significant variations within the EU. The arithmetic average is 2.3 per cent but, for the UK, the proportion is 9.5 percent, France 5.3 per cent, Denmark 4.2 per cent, Greece 4.2 per cent, and Poland 3.8 per cent. The UK and France together raise 58 per cent of the revenue from this type of taxation for the whole EU; in other words more than the rest of the EU combined. At one level, this is not surprising as the UK and France are two of the three largest economies in the EU. However, the UK raises 5.4 times the amount in recurrent property taxes each year than Germany, the largest economy in the EU, does and more than 21 members of the EU (including Germany, Italy, Spain, the Netherlands, and Poland) combined (EUROSTAT 2014).

Figure 3 shows the burden of recurrent property taxes as a percentage of incomes from capital and land in the EU using a methodology developed by Walters (2013). Incomes were derived by taking the gross value added (total output less that the part used for intermediate consumption) and deducting employee compensation (wages and salaries, plus employers' social contributions). The average for the EU is 1.9 percent of non-employment incomes being raised by recurrent property taxes. The UK raises 8.4 percent, France 6.2 per cent and Denmark 6 per cent. Poland, which raises the equivalent of 2.4 per cent of non-employment incomes from recurrent property taxes, is ranked $8^{\text {th }}$ in the EU.

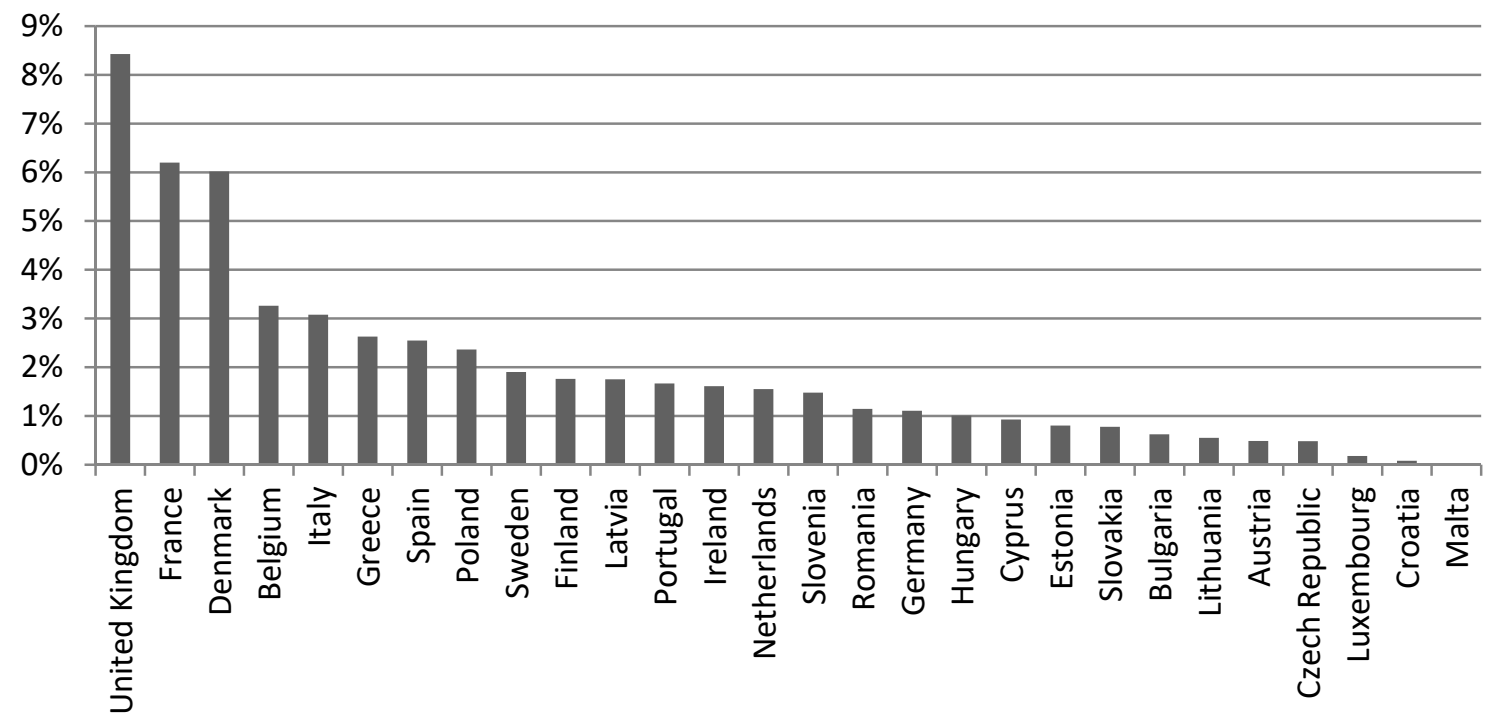

Fig. 3 Recurrent Taxes on Immovable Property in the EU as a Percentage of Gross Value Added Less Employee Compensation. Source: calculated from Eurostat (2014).

One reason why recurrent property taxes are relatively lightly used is because oftentimes, they are not based on the value of the property. Value-based taxes are levied according to the market value of the property. Commonly, recurrent property taxes have a different tax base, such as the size of the property, which can result in large low value properties paying higher tax rates than smaller valuable ones. Sometimes area-based taxes are moderated by factors such as construction quality, location, or land fertility but, although these may influence value, the resulting tax is not value-based. Unless value-based taxes are used, the effective tax burden will vary between taxpayers and the government can have little idea as to what the effective tax burden actually is. Under such circumstances, governments may set recurrent property taxes at very low levels. In this way, governments can ensure that businesses and households in possession of low value properties can pay the tax even though governments do not know what the effective tax rate is. In such circumstances, many taxpayers who could afford to pay a higher tax rate are not required to do so, and the potential yield is low. As this can have adverse consequences for the economy and for the fairness of the tax system, it raises the question as to why countries do not make greater use of value-based recurrent taxes.

One of the countries that continues to have a predominately area-based property tax system is Poland. The property tax system in Poland has its own autonomous history. It was created and is validated in two completely different systems (КОКОт 2009). One of them considers the value of real estate as the tax base; the other, their physical parameters, in particular the area (EUROPEJSKIE... 2003). The current system is the result of constant changes to the rules that make it up. It was created as a result of their permanent adaptation to the current political situation, but, despite these changes, is 
still largely shaped by the past social and economic system. Ex post, its construction indicates the main directions of these changes (ETEL, 2001):

- the gradual unification of property taxes leading to the creation of a group of benefits in which the taxable amount is the area of real estate,

- striving to simplify the construction of individual taxes, and

- continuous improvement of existing regulations, without attempts to implement a thorough reform of the system.

The real estate taxation system in Poland, in its present form, has been regulated by the provisions of three legal acts and includes the taxes on real estate, agricultural land, and forestry. It is not possible within the confines of this article to provide a detailed description of the taxes, thus only the most important regulations related to property taxation are presented in general terms.

The following real estate or construction objects are subject to real estate tax:

- land,

- buildings or their parts,

- buildings or their parts related to running a business.

The tax base is:

- for land: the area,

- for buildings or parts thereof: the usable area,

- for buildings or their parts related to running a business: the value.

The tax rate is determined by the municipal council, with the exception that they cannot exceed statutory rates, updated annually by the Minister of Finance with an announcement published in the Polish Monitor. The maximum rates on real estate in Poland for the period from 2010-2017 are shown in Table 1.

Table 1

The maximum rates on real estate in Poland

\begin{tabular}{|c|c|c|c|c|c|c|c|c|c|}
\hline \multicolumn{10}{|c|}{ Real estate tax in Poland } \\
\hline $\mathrm{Ma}$ & $\begin{array}{c}\text { imum rates of property tax (rate per } 1 \mathrm{sqm} /{ }^{*} \text { based } \\
\text { on value) }\end{array}$ & 2010 & 2011 & 2012 & 2013 & 2014 & 2015 & 2016 & 2017 \\
\hline 1 & $\begin{array}{l}\text { on buildings and their parts used to run a business } \\
\text { [PLN] }\end{array}$ & 20.51 & 21.05 & 21.94 & 22.82 & 23.03 & 23.13 & 22.86 & 22.66 \\
\hline 2 & on residential buildings or their parts [PLN] & 0.65 & 0.67 & 0.70 & 0.73 & 0.74 & 0.75 & 0.75 & 0.75 \\
\hline 3 & on other buildings or their parts [PLN] & 6.88 & 7.06 & 7.36 & 7.66 & 7.73 & 7.77 & 7.68 & 7.62 \\
\hline 4 & $\begin{array}{l}\text { on land associated with running a business, } \\
\text { regardless of the manner in which land and } \\
\text { buildings are classified in the register [PLN] }\end{array}$ & 0.77 & 0.80 & 0.84 & 0.88 & 0.89 & 0.90 & 0.89 & 0.89 \\
\hline 5 & on other land, e.g. for housing [PLN] & 0.39 & 0.41 & 0.43 & 0.45 & 0.46 & 0.47 & 0.47 & 0.47 \\
\hline 6 & on buildings [\%] & 2.00 & 2.00 & 2.00 & 2.00 & 2.00 & 2.00 & 2.00 & 2.00 \\
\hline 7 & $\begin{array}{l}\text { on buildings or parts of buildings occupied for } \\
\text { running a business in the field of providing health } \\
\text { services [PLN] }\end{array}$ & 4.16 & 4.27 & 4.45 & 4.63 & 4.68 & 4.70 & 4.65 & 4.61 \\
\hline
\end{tabular}

Source: Ministry of Finance in Poland.

When determining the number of rates from property tax to be used by the commune council (up to the upper limit specified by the Minister of Finance), it is possible to differentiate the amount for particular types of taxation items, taking into account the elements listed in the legal provisions. The types of elements that the Commune Council may take into account when differentiating tax rates are presented in Table 2.

Table 2

Types of elements differentiating the real estate tax rate in Poland

\begin{tabular}{cccc}
\hline & \multicolumn{4}{c}{ Subject of taxation } \\
\cline { 2 - 4 } Element & Land & $\begin{array}{c}\text { Buildings or theirs } \\
\text { parts (residential) }\end{array}$ & $\begin{array}{c}\text { Buildings or their } \\
\text { parts (other) }\end{array}$ \\
\hline Location & + & + & + \\
\hline Type of business & + & & + \\
\hline
\end{tabular}




\begin{tabular}{ccc}
\hline Type of building & + & + \\
\hline Land destination & + & \\
\hline Land use & + & + \\
\hline Technical condition & & + \\
\hline Age of the building & & + \\
\hline
\end{tabular}

Source: Own study on the basis of Law on Local Taxes and Fees dated 12nd January 1991

Dz.U.2017.1785 consolidated text 2017.09.27.

Despite the fact that in the Polish legal order there is the possibility of differentiating rates of property tax, it is rare for municipalities to use this option. Unfortunately, despite the fact that introducing a cadastral tax in Poland is the subject of debates and discussions among both scientists as well as state officials and politicians, so far there is no widely accepted idea of this task. This is despite the current system deisincentivizing the proper allocation of capital and space, and its equity raising widespread doubts. (RENIGIER-BIŁOZOR 2017) The introduction of the legal possibility of differentiating tax rates based on the area of real estate has failed miserably.

\section{Preconditions for successful recurrent property tax reform}

The literature suggests that the factors influencing the use of recurrent property taxes include income level, the extent of urbanization, the openness of the economy, the legal heritage, and the degree to of decentralization of the government (NORREGAARD 2013; DE CESARE 2012). These are factors that are difficult to change through policy intervention, thus in 2014-15, the World Bank and FAO carried out a research project into property taxation and valuation in the Europe and Central Asia Region with the intention of identifying the factors aiding successful value-based recurrent property tax projects and to share good practice on the lessons learned from reforms undertaken within the framework of the Voluntary Guidelines on the Responsible Governance of Tenure (COMMITTEE ON WORLD FOOD SECURITY 2012). Case studies were drawn from eight countries in the region. Lithuania (ALMY 2016) has a well-developed and highly centralized system of valuation and property tax collection. Moldova, Poland, and Slovenia (BUZU 2016; WALACIK 2016; ŽIBRIK 2016) have developed mass valuation systems but, for different reasons, these have not been fully implemented. Albania, Kazakhstan, Serbia, and Turkey (GJIKA 2016; MCCLUSKEY 2016; RAŠKOVIĆ et al. 2016; GÜNEŞ, YILDIZ 2016) have undertaken preparatory work, such as piloting mass valuations. In addition, the Netherlands (KUIJPER, KATHMANN, 2016) were included for comparison with the emerging economies of the ECA region as a country with a mature recurrent property tax system that uses mass valuations updated each year. The template asked authors to explain the property tax system in their country and its role in the country's public finances at national and local levels, how property taxes were assessed, the valuation standards adopted, the data sources used in valuation and their reliability, the methods employed in mass valuation, and the lessons learned from property tax reforms. The research identified four main areas in which technical problems needed to be overcome: the quality of property registration, the quality of price data, the valuation infrastructure, and the quality of tax collection (GROVER et al. 2016; GROVER et al. 2017).

In principle, recurrent property taxes should be hard to avoid as they fall on immobile assets. However, this depends on the comprehensiveness of land registration. In other words, whether there is a comprehensive list of the immobile assets to be taxed and whether such a list is maintained so as to be current in its coverage. In Moldova, the mass valuation system using market values covers urban housing and industrial and commercial properties but not rural housing or agricultural land, for which there has been no systematic first registration. Agricultural land is taxed by area and rural housing on its inventory value (BUZU 2016). In Albania, it is estimated that initial registration has been completed for 83 per cent of rural cadastral zones but only 25 per cent of urban ones (WORLD BANK 2011). The Immovable Property Register Office does not register properties until all claims have been resolved, which means that there is incomplete registration of disputed areas and informal settlements. Serbia has a significant problem with unregistered properties, with estimates that these amount to 14 per cent of apartments, 22 per cent of family homes, and 15 per cent of commercial properties (ARSIĆ et al. 2012). In Kazakhstan, it is mandatory to register changes of ownership from the state to the private sector, but not subsequent transfers of ownership between private owners (MCCLUSKEY 2016).

Registers need to include key information about the properties. This includes three-dimensional 
rights and any rights over ancillary spaces, and not just buildings, which may be sub-divided, or their footprints. Since the aim in value-based recurrent property taxation is to take a sample of properties for which there is recent market price evidence and apply this to comparable properties for which there have been no recent transactions, it is necessary to have accurate and consistent information about the characteristics of the properties. Since price data is usually reduced to unit values, the properties must be measured in a consistent way. In Turkey, for example, different mortgage banks define the sizes of properties in different ways, such as whether external terraces are included or not (GÜNEŞ, YILDIZ 2016).

The shape of Polish property registration system is formed by numerous Legal Acts that precisely determine the rules concerning the functioning of particular sources, but for the purposes of property taxation the most important ones are property right registers and land and buildings registers. Property right registers are public records kept by district courts in order to establish the legal status of real estate, as well as to increase the security of legal transactions in real estate (DYDENKO ed. 2015). They can be kept for four tax types of real estate: for landed properties, for buildings real estate, premises and cooperative ownership rights to premises. Information is included in the land and mortgage registers regarding both:

- the physical dimension of the real estate - the description of the real property included in Section I of the land and mortgage register, and

- intangible property - including property contained in Section II, charges included in Section III, and mortgages included in Section IV (KoNOWALCZUK 2016).

The real estate cadaster is, in practice, an inventory of land and buildings and premises run by starosts (BELNIAK, WIERZCHOWSKI 2005). This register is intended to record the physical condition of the property and the data relating to the property. It serves as the basis for entry in the land and mortgage registers and, therefore, this information covers the physical dimensions of the property. The second element of the cadaster constitutes a register of prices and property values prepared for the needs of official statistics, and will be discussed later in this work.

In connection with the changes in the political system in the 1980s, Poland's entry into the European Union, the development of an information society, and the introduction of widely understood technology, issues regarding the quality of data contained in real estate registers and the availability of this data have become major challenges. Work on computerization of court registers in Poland began in 1995 and was aimed at replacing the then paper books with electronic books, as well as the creation of a nationwide, uniform database of land and mortgage registers (STEFAŃSKA 2011). The preparatory work lasted for several years in order to provide public, free access to land and mortgage registers in 2010 through the official website of the Ministry of Justice, through which you can view and print land and mortgage registers on your own, free of charge, assuming that their numbers are known. Entries in paper books have been discontinued and the implemented IT system has replaced paper records, but the migration of books into electronic databases has not yet been completed. After the entry into force of the Act of June 5, 214 amending the Geodetic and Cartographic Acts, both extracts and outlines from the cadaster became public. However, there are no information systems that are able to link the cadaster with the register described above. Access to data is only in paper form and has to be paid for.

Regarding the integration of the real estate cadaster with other systems in Poland, several initiatives emerged, the most important of which was the Construction of an Integrated Real Estate System (ZSIN). The main tasks of ZSIN include:

- maintaining a central repository of copies of cadaster data sets,

- monitoring the consistency and quality of cadaster data sets,

- exchange of data in the form of electronic documents between the cadaster and, inter alia, property registers,

- checking of land and mortgage registers by land courts,

- verification of compliance of cadaster data with data contained in, among others, property registers,

- making available to public administration bodies cadaster data sets necessary for the implementation of their statutory tasks,

- conducting spatial analyses on cadaster data sets covering areas larger than one poviat. 
The vast majority of the works covered by the ZSIN have already been implemented. This gave a wide range of possibilities in scientific work supporting, amongst many, property tax systems (JANOWSKI 2018; JANOWSKI, SZULWIC 2014; BRZEZICKA, WISNIEWSKI 2016). The planned completion date is set for 2020. After this process, all data including cadastral are to meet the highest quality standards and their availability is to be facilitated by potential recipients in accordance with standards adopted throughout the European Union.

Assessments for value-based recurrent property taxes make use of price data from recent transactions and apply them to comparable properties. This implies that such taxes require good evidence of transaction prices. The prices required depend on the tax base. Some recurrent property taxes are assessed on the capital value of properties and thus require evidence of achieved sales prices. Others are assessed on the annual value and require evidence of market rentals. If capital values are not available but rentals and yields are known, they can be estimated using the income method. Good market evidence requires efficient and transparent markets with adequate numbers of transactions of each type of property in each location. Without these, assessors are faced with empty cells for which there is no comparable price information. Cells can be amalgamated where transactions are absent but this risks producing mixed collectives, which contain properties which are not strictly comparable with each other.

An ideal source of data are prices declared when changes of ownership are registered as these should be a comprehensive record of transactions. Inevitably some data cleaning is required, for example to remove transactions which were not at arm's length or where the property was bought for redevelopment. Problems can arise where inaccurate prices are declared in order to evade taxes or transfer fees and there are weak enforcement mechanisms by tax authorities and bodies involved in the registration, such as notaries. In Moldova property transfer taxes and notary and registration fees are not high, at 0.5 per cent, 0.1 per cent and 100 leu respectively; it is thought, however, that declared contract prices understate the true sales price in 90 per cent of cases because of a capital gains tax levied at 18 per cent of the difference between sales prices and those produced by mass valuation between 2004 and 2009 (BUZU 2016). Notaries appear to be reluctant to force disclosure of the real prices even though their fees are based upon declared transaction prices. Faced with this problem, mass valuation in Moldova supplemented prices from sales contracts with asking prices and data from realtors, valuers, and auctions (BUZU 2016). The capital gains tax is in the course of being amended and is likely to apply to prime residences only if sold within five years, making it a tax that will fall primarily on speculative gains. Turkey has faced similar problems due to a land registry fee of 4 per cent of the transaction price. Two mass valuation pilot studies indicated that annual property tax yields should be 2.94 and 1.88 times the sums actually raised in these areas (GÜNEŞ and YILDIZ 2016). As mortgage valuations in Turkey are regulated by the Capital Markets Board and only licensed valuers can carry them out, they are a more reliable source of price data than declared transaction prices. By contrast, declared prices in Lithuania appear to be relatively accurate because transfer taxes and fees are low, at 0.8 per cent of value, and a capital gains tax on sales made within five years discourages purchasers from under-declarations, whilst the use of mortgages to finance property acquisition favors accurate assessment of collateral (ALMY 2016).

Polish property transaction data is also based on property buyers' and sellers' declarations. The data seems accurate even though the transfer tax in Poland equals 2 per cent of the property market value. The maximum amount of the notary fee has been set by the law, that's why the property right transfers are limited. In order to verify the declared property prices, there are special procedures and responsible authorities for this - tax offices (MANZHYNSKI et al. 2018). Because of the fact that transfer tax is based on the market value of the property, in theory, data cleaning should not be necessary. In practice there are situations where property prices are not adequate to the property features, but those situations are rare (RENIGIER-BIEOZOR, D’ AMATO 2017).

Countries that have successfully introduced value-based recurrent property taxes have developed their valuation infrastructure prior to commencing reforms. Valuation infrastructure includes valuation standards that are compatible with internationally-recognized ones, standards for the consistent measurement of properties, and determination of who is qualified to act as a valuer. These countries established qualifications for valuers, including the education and training they must undertake, the experience they are required to possess, examinations, and the requirement for continuing professional development. They have ethical standards and codes of professional practice for valuers. Enforcement of these standards requires a licensing system or developed professional 
negligence law with a requirement on clients to use only valuers who follow the standards. Assessment of value-based recurrent property taxes requires valuers to undertake the necessary valuations. This applies even if a mass valuation system is used as valuers are required to advise on models, data cleansing and data gathering, to undertake valuations of properties that cannot be modelled statistically, and to be involved in appeals. In such systems, they are normally a part of a team of statisticians, econometricians, and data programmers, but are nevertheless an essential part of it. In Lithuania, the Association of Property Valuers was established in 1994. General property valuation principles were approved by the Government in 1995 and the Law on the Fundamentals of Valuation of 1999 established valuation procedures. The certification of valuers began in 1998 (ALMY 2016). In Moldova, valuations are regulated by the Law on Valuation Activities (2002) and can only be undertaken by licensed valuation companies that have at least one licensed valuer. Moldova's standards are based on European Valuation Standards (BUZU 2016). In both Lithuania and Moldova licensed valuers have been employed in local cadaster offices and national headquarters as part of the mass valuation system.

Poland has also developed detailed systems of valuation infrastructure that have been written in basic legal acts and valuation standards. The professional standards of property appraisers in Poland are closely related to the development of the profession and professional organizations. The inspiration to create the first methodological basis for the valuation became foreign experience, in particular the TEGoVA (during this TEGoVoFA) and RICS standards. The first professional standards which the National Council of Polish Federation of Property Valuers' Associations adopted and published were in 1995. Over the years, new editions and supplements of the set of standards appeared over the period from 1996 to-2004. Standards, constituting for many years the first methodological basis, due to changes in law over the years, became merely an auxiliary material, similar to any other types of publications. Changes in the perception of standards coincided with the significant development of science and practice in the field of valuation in Poland, Europe, and the world. The Polish Federation of Valuers' Associations took up the challenge a few years ago to develop professional standards based on the latest solutions proposed by TEGoVA and IVSC. However, the harmonization of valuation rules applicable worldwide and in Europe with the national system has been limited in some areas. This was related to the specific regulations in force in Poland. The valuation standards constitute a rich achievement encompassing both general issues as well as very detailed issues, including those specific only for Polish realities. The present system and its components are constantly developing in order to adapt them to the latest achievements in the field of valuation theory and practice and to harmonize them more and more with the European and global systems. According to the latest amendment to the law, the minister responsible for construction, planning, spatial development and housing shall establish and publish applicable professional standards.

In order to become a property valuer in Poland, a person must:

- have full legal capacity,

- have not been punished for a crime against a state institution or local self-government, for a crime against the administration of justice, for a crime against the credibility of documents, for an offence against property, for an offense against economic turnover, for an offence against trading in money and securities, or for a tax offence,

- have completed higher education,

- have completed postgraduate studies in real estate valuation,

- have completed at least 6 months of professional practice in real estate valuation,

- have passed the qualification proceedings, including an exam giving entitlement to estimate property.

There is no point in having good systems for assessing value-based recurrent property taxes unless there are also efficient systems for billing taxpayers and collecting the taxes that have been billed. The costs of managing the tax system should be a minimal percentage of the revenue levied as the objective is to raise funds for the government and not to create employment in tax administration. Collection rates vary considerably. Moldova is able to collect 95 per cent of the value-based assessments on individuals and 90 per cent of those on legal entities (BuZU 2016). By contrast, the average collection rate in Albania is below 50 per cent in the largest urban areas (GJIKA 2016). The problem in Albania is partly cultural, where public opinion does not censure tax evasion, and partly 
due to weak enforcement mechanisms. Arrears can only be collected when an official document is required, which, given the level of informal transactions, is problematic as the public can find ways of avoiding the need for official documents. Weak collection mechanisms have resulted in governments turning to utility companies to help collect property taxes. This can be a solution as households and business consume electricity and water, but does presume that the utility companies are able to collect what they bill. Improving the property tax system requires heavy investment up front in people, training, systems, and equipment before the benefits of increased revenue appear. In Serbia, collection rates are undermined by a poor collection and accounting system that make it difficult for citizens to track what they owe, and a lack of capacity, including outdated equipment and poor accommodation (RAŠKOVIĆ et al. 2016). In Moldova, the failure to extend the mass valuation system into rural areas is believed to be due to the fact that the cost of systematic first registration will fall on the central government, but the benefits from being able to increase property tax revenues accrue to local governments. The financial constraints on the government have meant this is not a high priority.

There are significant economies of scale in property taxes, which means that low tax rates that yield relatively little revenue result in relatively high collection costs as a proportion of revenues. Extensive exemptions also depress tax yields. Many countries provide exemptions based on categories rather than on ability to pay. Thus, an exemption for military veterans can apply to former generals as well as privates, and one for disabled persons can exempt an entire household, even if there are other wage earners. In Moldova, extensive exemptions are made worse by a discount of 15 per cent if taxpayers pay at least six weeks before the payment deadline, with the result that exemptions amount to 27 per cent of the maximum tax revenue payable by individuals and 55 per cent of that for business entities (BuZU, 2016). The World Bank Land Governance Assessment Framework (2014) estimated that collection costs amounted to 43 per cent of the revenues collected in 2012. Mass valuation is able to bring down assessment costs significantly (ALMY 2014, 2016; BUZU 2016; KUIJPER, KATHMANN 2016) and on-line payment systems - the costs of collection, but there is significant up-front investment required to make these systems effective.

The problem that value-based recurrent property taxes encounter is that some taxpayers lack the liquidity to pay tax demands, as much of their wealth is tied up in the property. Typically these cashpoor asset-rich households are pensioners living in housing acquired through privatization or restitution, and whose income is a small state pension. Often, they were able to acquire their housing at nominal cost. For instance, in Slovenia, this was at about 10 per cent of its market value (ŽIBRIK 2016). The value of the assets may therefore bear little relationship to lifetime earnings. They are not income-producing and and thus do not generate the means with which to pay taxes (MALME, YOUNGMAN 2001). The problem is that one person's relief is another person's higher tax rate, and there is a danger of biasing the tax system so that those with limited assets but the ability to earn an income end up subsidizing those with greater wealth than them.

\section{Resistance to property tax reform}

A logical case can be made for tax reform so that recurrent property taxes are levied by value. However, this, by itself, does not mean that the reform will go ahead, even in situations in which the pre-conditions for effective reform have largely been met, as in Poland. The first work on the reform of the tax system in Poland began in 1990, however, for various reasons, they were discontinued. First of all, there was no political will to seriously and comprehensively deal with the topic. The political barrier is not the only one that has been faced by reform. What has been emphasized in recent years and what seems to be almost a solved problem is a full and reliable record base. The lack of legal regulations in this area is being gradually minimized as a barrier to changing the method of taxation. Although the act on the cadastral system has not been prepared, other legal provisions, such as the Amendment to the Geodetic and Cartographic Law Act, have already been implemented. Another barrier to implementing the reform seems to be the economic barrier. Despite the fact that a significant part of the costs has already been incurred (such as the creation of the Integrated Cadastral System), the estimated costs of about PLN 2 billion appears to be a key obstacle (CIAK, WĄSEWICZ 2014). The lack of information about the proposed reform passed on in a clear way to the public is another obstacle to the reform. Previous actions of public authorities did not aim at explaining either the positive or negative features of the new solution. Therefore, despite the numerous legislative and economic barriers outlined above, the social barrier may be the most difficult barrier to overcome. Currently, the Ministry of Finance is not carrying out work on a real estate tax system based on the 
value of real estate. As emphasized above, it requires complete data on the value of the property. Currently, due to their absence and the cost of implementing this solution, the introduction of a valuebased property tax is impossible (MILEWSKA 2016).

Poland's experience is not unique. Two other case study countries, Slovenia and Moldova, have also experienced stalled property tax reforms. Slovenia began mass valuation in 2006 with the valuations being sent out in 2009, and the Government approving the models in 2012. It planned to increase tax rates on residential properties so that the gap between the rates on these and commercial properties would be narrowed. Business properties paid over 70 per cent of property taxes and the effective tax rate was, on average, 0.7 per cent of the market value whereas that for residential properties was, on average, only 0.08 per cent. Effective tax rates between municipalities for residential properties varied from 0.002 to 0.4 per cent of the market value and for business properties from 0.1 to over 3.0 per cent, so a degree of harmonization could be justified on the grounds of equity. The government also planned to retain part of the increase in revenues for its own use rather than for these to be entirely passed on to municipalities. The plan would have seen an increase in the yield from property tax from 0.6 to 1.2 per cent of GDP, with the government taking 50 per cent of the revenue for the state budget. What brought the implementation to a halt was a challenge on constitutional grounds from municipalities faced with losing some of their tax determining powers and residential taxpayers faced with high taxes. The changes would have reduced the autonomy of local governments to set their own tax rates, though they could still vary rates from the national standard by 50 per cent in either direction. The Constitutional Court did not rule against a property tax levied on market values but did prevent the valuations from mass valuation being used for property tax on the grounds that they did not provide sufficient legal certainty, something that improvements in the appeal system could overcome. The valuations can continue to be used for other purposes, including determining eligibility for social security and to check the value of the collateral being held by banks against mortgages. The Court also found that limits on the abilities of local authorities to set their own rates were unconstitutional (ŽIBRIK 2016). Work on trying to overcome the objections continues and agreement appears to have been reached about the road ahead, though it still requires legislation. The outcome points to the need to ensure that the new assessments are perceived to be fair through devices such as an independent appeals system in which taxpayers can challenge both the methods used and the evidence on which assessments have been made. The government did not just seek to introduce a new method of assessment but also to change the distribution of the revenue between central and local governments and to reduce the autonomy of the latter. Whilst such changes might have been possible over time, to introduce them all at once meant that technical improvements in tax assessment became caught up in a constitutional struggle between different branches of government.

In Moldova, the Tax Code was amended in 2000 to introduce value-based property tax assessment and a single property tax to replace the land tax and the tax on buildings and structures. Mass valuation was launched in 2004 and all properties were intended to be valued within five years, with an additional type of property being added to the system each year. However, the valuations have not been completed, with mass valuation covering only about 12.5 per cent of properties, although these are amongst the most valuable properties since the new system covers business properties and urban housing. The old dual property tax system remains in place for the properties not included in the mass valuation system, principally agricultural land and rural housing. Before valuation of these can take place, the systematic registration of the properties must first take place, and the government has not allocated the funding for this to take place in rural areas or to delineate state and private properties. As was noted earlier, although the cost of registration is a central government responsibility, the revenue benefits from mass valuation would be enjoyed by local governments. The Government of Moldova has been faced with financial problems and this has also meant that none of the revaluations of mass valuations, which should take place every three years, have taken place either. It has been estimated that appraised values for apartments in Chisinau are 44 per cent of current market values, for houses 48 per cent, and for retail properties and offices 89 per cent (BUZU 2016). There is also the fear that a switch to market values for agricultural land could result in lower revenue for local governments because of falls in the values of such properties, which could make local governments in rural areas even more dependent on intergovernmental fiscal transfers. 
The use of recurrent property taxes often seems to trigger hostile reactions from the population, which can seem out of proportion to the tax burden they create. This may be because they are highly visible in ways that consumption taxes, like value added tax and income tax, social security contributions, and profits taxes are not. For households, the payment of property tax usually involves handing over money from taxed income to a tax authority rather than this process being hidden through tax deductions at source from earnings or with retailers acting as unseen tax collectors of consumption taxes. The local public services they are used to fund are also highly visible with the population having a direct experience of them and their management that they do not of many other areas of government expenditure, such as defense. Recurrent property taxes are hard to avoid so legal tax minimization planning is not usually feasible. Those particularly affected by property taxes can be expected to articulate in their opposition and to possess resources they can deploy to oppose change. Surprisingly, opposition can often be encountered from those that one would expect to benefit from higher taxes on wealth to fund public services. All of these point to the need for careful planning of property tax reforms and for them to be accompanied by careful marketing of the initiative showing how benefits follow from reform.

Although governance is, in principle, enhanced by linking the costs and benefits of public services so that citizens can make informed choices about trade-offs, politically this can be problematic, with anticipated losses attracting more attention than possible gains. It would appear to be much easier for local politicians to increase tax yields by improving collection rates by bringing into the tax system properties not being taxed than to improve the method of tax assessment. There are likely to be fewer losers, and they are unlikely to attract much public sympathy for having evaded taxes in the past. Such action brings an immediate increase in revenue to sweeten any tax increases and the cost of doing this through checking tax rolls against utility bills, electoral registers, and orthophotos is not prohibitive. However, these bring one-off benefits seeing as how once untaxed properties are included in the tax rolls, there is no further increase in revenue to be obtained. Moving to a value base with regular revaluations is a gift that keeps on giving as revenue continues to be boosted by the capture of the increase in values that economic, urban, and demographic growth can produce.

Property taxes are generally local taxes. The legislation to change them has to be passed by parliaments under the direction of national governments, but the impact is usually on local finances. As shown by the example of Slovenia, this is capable of provoking constitutional conflicts, particularly if the central government removes powers from local authorities to determine tax rates or their powers to carry out assessments. It can also result in central governments being uninterested in local taxes or unwilling, as in the case of Moldova, to commit resources to improving them. Part of the problem is likely to be that governments do not appreciate how the finances of the various parts of the public sector are interlinked. Failure to exploit the full potential of property taxation has repercussions on inter-governmental fiscal transfers, whether in the form of grants to local authorities by central government or tax sharing arrangements. If local tax potential is not fully realized, then this impacts budgetary deficits and borrowing by central governments. This may be why property tax reform may be a priority for central governments only in times of financial crisis and when they come under pressure from bodies like the International Monetary Fund. At other times, inter-governmental fiscal transfers may seem to be a good way of controlling local authorities and treating them as "clients".

There is an uphill battle to convince ministries of finance to support property tax reform. Modern trends are to create one-stop shops for business relationships with the tax authorities, capable of dealing with profits and other taxes on the businesses themselves, their role as tax collectors of income tax and social security contributions from their employees, and their collection of consumption taxes like value added tax. Property taxes do not fit easily into this mould. They require specialist assessment methods being based on the value of properties rather than financial transactions. They require specialist tax rolls to be maintained and separate collection methods. Officials in ministries of finance are not specialists in valuation and find themselves acting outside of their comfort zones when it comes to property taxes. They are seen as being the province of ministries of the local government or construction, which are usually much lower in the political pecking order than ministries of finance. Financial pressures, particularly external ones from creditors or the IMF, can raise the priority ministries of finance give to what they are likely to regard as local government finance reforms. 


\section{Conclusions}

Most countries have recurrent property taxes, but they typically raise relatively little revenue as a proportion of GDP or of total tax revenues. There are some countries which are exceptions, such as the UK and France and former British colonies, such as the USA and New Zealand. Just as the AustroHungarian Empire left behind its grundbuch in countries that were once part of it, so the British Empire seems to have left behind the rating system, a recurrent property tax. The case for making greater use of recurrent property taxes by placing them on a value rather than area base can be made in terms of improved equity and efficiency, and to combat globalization eroding the yield from other taxes. There are some clear technical obstacles to be overcome including the need for a comprehensive register of properties, having good data sources about achieved property transaction prices, a valuation infrastructure, and an efficient system of tax collection. Putting these in place can be expensive and requires significant investment up front, before there is a benefit in the form of increased tax yields. Some of these costs can be offset by bilateral donors, assistance from FAO, and loans from the World Bank. Usually such projects show a significant return on the capital employed.

However, there are also political and governance problems to overcome, meaning that even countries like Poland, which have largely overcome the technical obstacles, can struggle to implement property tax reforms. Recurrent property taxes are usually levied to support local governments but reform requires the support of the central government in passing legislation and providing resources. Even though improving property tax yields has an impact on inter-governmental fiscal transfers and the government finances as a whole, central government may be reluctant to commit resources to this area or, when doing so, can find itself enmeshed in constitutional conflicts. Ministries of finance, who ought to be the champions of tax reform, find themselves operating outside of their comfort zones with a tax that operates in a very different way than those they are used to administering and requires a different means of assessment. It may be that significant property tax reform sometimes requires a financial crisis to give it a boost. As Rahm Emanuel, President Obama's Chief of Staff, probably quoting Winston Churchill, said, you should never let a serious crisis go to waste. It makes possible what was previously impossible.

Despite the fact that Poland made a serious effort to decrease major barriers on property taxation reform, political and social support is still insufficient. The aim of the paper was to show examples of solving the problem by other countries so that they can provide a valuable lesson for Poland.

\section{References}

Almy R., 2014, Valuation and Assessment of Immovable Property, OECD Working Papers on Fiscal Federalism, No. 19, O.E.C.D,. Publishing, Paris.

ARsić M., RANĐelović S., Bućić A., VASILjević D., 2012, Property Tax Reforms in Serbia: Results and Perspectives, Deutsche Gesellschaft für Internationale Zusammenarbeit (GIZ) GmbH, Belgrade.

BELNIAK S., WIERZCHOWSKI M., 2005, Sources of Information on Real Estate, Małopolska Wyższa Szkoła Ekonomiczna w Tarnowie, Tarnów.

BRZEZICKA J., WISNIEWSKI R., 2016, Translocality on the Real Estate Market, Land Use Policy, 55, 166-181.

BuZu O., 2016, Property Assessment and Taxation in the Republic of Moldova, Land Tenure Journal, issue $15 / 2$, pp. 63 - 81.

CIAK J., WĄSEWICZ B., 2014, Cadastre as a Condition of the Property Tax System Reforms in Poland, Prawo $\begin{array}{llllll}\text { Budżetowe Państwa i Samorządu 4(2)2014, pp. 9-29, DOI: } & \text { i }\end{array}$ http://dx.doi.org/10.12775/PBPS.2014.035.

COMMITTEE ON WORLD FOOD SECURITY, 2012, Voluntary Guidelines on the Responsible Governance of Tenure of Land, Fisheries and Forests in the context of National Food Security, available from http://www.fao.org/docrep/016/i2801e/i2801e.pdf

De CESARE C. M., 2012, Improving the Performance of the Property Tax in Latin America, Lincoln Institute of Land Policy, Cambridge, MA.

Etel L., 2003, European Systems of Property Taxation, Biuro Studiów i Analiz, Kancelaria Sejmu, Warsaw.

ELET L., 2001, Property Taxation, Temida 2 Białystok.

EUROSTAT, 2014, Taxation Trends in the European Union: Data for EU Member States, Iceland and Norway, European Union, Luxembourg.

GJIKA A., 2016, Property Taxation in Albania, Land Tenure Journal, issue 2, pp. 183 - 202. 
Grover R.J., TÖRhÖNEn M-P., Munro-FAure P,. AnAND A., 2016, Property Valuation and Taxation for Fiscal Sustainability and Improved Local Governance in the ECA Region, Land Tenure Journal, issue $15 / 2$, pp. 7 - 27.

Grover R.J., TÖRHÖNEN M-P., MunRO-FAure P., ANAND A., 2017, Achieving Successful Implementation of Value-based Property Tax Reforms in Emerging European Economies, Journal of European Real Estate Research, volume 10 No 1, pp 91 - 106.

GÜNEŞ T., YILDIZ Ü., 2016, Property Valuation and Taxation for Improving Local Governance in Turkey, Land Tenure Journal, issue 15/2, pp. 141 - 160.

JANOWSKI A., 2018, The Circle Object Detection with the Use of Msplit Estimation, E3S Web Conf., 26 (2018) 00014, DOI: https:// doi.org/10.1051/e3sconf/20182600014 Web of science.

JANOWSKI A., SzUlwiC J., 2014, Determination of the City Centre. Study for the Trójmiasto Agglomeration, 7th International Conference of Education, Research and Innovation, Seville, Spain. ISBN: 978-84617-2484-0, str. 1665.

JOHANSSON Å., HeAdy C., ARNOLD J., BRYS, B., VARTIA L., 2008, Tax and Economic Growth, Economics Department Working Paper No 620, OECD, http:/ / www.oecd.org/tax/tax-policy/41000592.pdf.

KOKOT S., 2009, Problems of Taxation of Real-estate in Context of the Communal Real-Estate Economy, Administratio Locorum 8(1), pp. 44-55.

KonowalczUK K., 2016, Electronic Sources of Information on Real Estate in Poland, Biuletyn Stowarzyszenia Rzeczoznawców Majątkowych Województwa Wielkopolskiego, Nr /2016 (45), pp. 89-100.

KuijPer M., KATHMANN R.M., 2016, Property Valuation and Taxation in the Netherlands, Land Tenure Journal, issue15/2, pp. 47 - 61.

MaLme J.H., Youngman J.M., 2001, Introduction, in Malme, J.H. and Youngman, J.M. (editors), The Development of Property Taxation in Economies in Transition: Case Studies from Central and Eastern Europe, pp. 1-10, The World Bank, Washington D.C.

MANZHYNSKI S., ŹRÓBEK S., BATURA O., ZYSK E., 2018, Why the Market Value of Residential Premises and the Costs of its Purchase Differ: The Examples of Belarus and Poland, Land Use Policy, Vol. 71, pp. 530539.

MCCluskey W. J., 2016, Real Property Taxation in the Republic of Kazakhstan, Land Tenure Journal, issue 15/2, pp 119 - 138.

MileWSKA A., 2016, Problems of Real Estate Taxation in Poland - Selected Aspects, Annales H - Oeconomia, vol. L, 1, pp. 391-398. DOI:10.17951/h.2016.50.1.391.

NORREGAARD J., 2013, Taxing Immovable Property - Revenue Potential and Implementation Challenges, IMF Working Paper, WP/13/129, International Monetary Fund, Washington D.C.

RENIGIER-BIŁOZOR M., 2017, Modern Classification System of Real Estate Markets. GEODETSKI VESTNIK. Vol. 61, No. 3. DOI:10.15292//geodetski-vestnik.2017.03.441-460.

Renigier-BiŁozor M., D'AmAto M., 2017, The Valuation of the Hope Value for Real Estate Development, Real Estate Management and Valuation, vol. 25, no. 2, pp. 91-101.

RAŠKović M., Grover R. J., JordAnOvić O., 2016, Serbia Case Study on Property Valuation and Taxation, Land Tenure Journal, issue 15/2, pp. 163 - 180.

TrojaneK M., KisiaŁA W., 2018, Recurrent Property Taxes in Communal Budgets - Identification of Types of Communes and their Spatial Differentiation, Real Estate Management and Valuation, vol. 26, no. 1, pp. 39-50.

WALACIK M., 2016, Property Taxation in Poland: Legislation without Implementation, Land Tenure Journal, issue 15/2, pp. $101-116$.

Walters L.C., 2013, Estimating Property Tax Revenue Potential, in McCluskey, W.J., Cornia, G.C. and Walters, L.C. (editors) A Primer on Property Tax: Administration and Policy, Blackwell Publishing, Chichester, UK, pp. 229-248.

WORLD BANK, 2011, Governance in the Protection of Immovable Property Rights in Albania: A Continuing Challenge, A World Bank Issue Brief, Report No. 62519-AL, World Bank, Washington, D.C.

WorLD BANK, 2011, Moldova Land Governance Assessment Framework (LGAF): Final Report (March, 2014) ŽIBRIK N., 2016, The Process of Introducing a Modern Real Property Tax in Slovenia, Land Tenure Journal, issue $15 / 2$, pp. 83 - 99.

STEFAŃSKA E., 2011, Elektroniczna Księga Wieczysta (Electronic Land and Mortgage Register), Lexis Nexis, Warszawa. 